\title{
Phytoprotection
}

\section{A note on the susceptibility of six red raspberry cultivars and Tayberry to fruit infection by late yellow rust}

\section{Luffman et D. Buszard}

Volume 71, numéro 2, 1990

URI : https://id.erudit.org/iderudit/705987ar

DOI : https://doi.org/10.7202/705987ar

Aller au sommaire du numéro

Éditeur(s)

Société de protection des plantes du Québec (SPPQ)l

ISSN

0031-9511 (imprimé)

1710-1603 (numérique)

Découvrir la revue

\section{Citer cet article}

Luffman, M. \& Buszard, D. (1990). A note on the susceptibility of six red raspberry cultivars and Tayberry to fruit infection by late yellow rust. Phytoprotection, 71(2), 93-95. https://doi.org/10.7202/705987ar
Résumé de l'article

Nous avons inoculé in vivo des grappes de fruits de six cultivars de framboisier rouge (Rubus idaeus) et de framboisier-ronce de Tay avec des éciospores et des urediniospores du Pucciniastrum americanum. Les résultats des deux inoculations étaient semblables. Deux cultivars, soit Nova et Royalty, et le framboisier-ronce de Tay étaient résistants à l'infection des fruits par la rouille jaune tardive tandis que les autres cultivars montraient différents degrés de sensibilité à l'infection par la rouille jaune tardive. Le cultivar Boyne montrait une résistance partielle. 


\title{
A note on the susceptibility of six red raspberry cultivars and Tayberry to fruit infection by late yellow rust
}

\author{
Margie Luffman \\ Agriculture Canada, Senator Hervé J. Michaud Experimental Farm, \\ P. O. Box 667, Bouctouche, New Brunswick, Canada EOA 1GO
}

\author{
Deborah Buszard \\ Department of Plant Science, Macdonald College of McGill University, \\ 21111 Lakeshore Rd., Sainte-Anne-de-Bellevue, Québec, Canada H9X 1CO
}

(Received 1989-05-08; accepted 1990-03-20)

Fruit clusters of six red raspberry (Rubus idaeus) cultivars and Tayberry were inoculated in vivo using aeciospores and urediniospores of Pucciniastrum americanum. The response was similar for both inocula. Two raspberry cultivars, Nova and Royalty, and Tayberry were apparently resistant to late yellow rust infection on fruits while the other raspberry cultivars exhibited differing degrees of susceptibility to late yellow rust. The cultivar Boyne exhibited some partial resistance.

Luffman, M., and D. Buszard. 1990. A note on the susceptibility of six red raspberry cultivars and Tayberry to fruit infection by late yellow rust. PHYTOPROTECTION 71 : 93-95.

Nous avons inoculé in vivo des grappes de fruits de six cultivars de framboisier rouge (Rubus idaeus) et de framboisier-ronce de Tay avec des éciospores et des urédiniospores du Pucciniastrum americanum. Les résultats des deux inoculations étaient semblables. Deux cultivars, soit Nova et Royalty, et le framboisier-ronce de Tay étaient résistants à l'infection des fruits par la rouille jaune tardive tandis que les autres cultivars montraient différents degrés de sensibilité à l'infection par la rouille jaune tardive. Le cultivar Boyne montrait une résistance partielle.

The occurrence of late yellow rust (Pucciniastrum americanum [Farl.] Arth.) on red raspberries (Rubus idaeus L. var. strigosus [Michx.] Maxim.) in the Atlantic provinces of Canada has been sporadic for many years. In 1984 and 1985 a serious outbreak occurred (Luffman and Buszard 1988). Nickerson and Mahar (1987) in Nova Scotia observed that the cultivar Carnival had less rust on the fruit than Festival, but the foliage was equally or more rusted. Similar observations were made in New Brunswick (M. Luffman, unpublished data). In order to examine more closely any differences between these two cultivars and others, fruit infections by late yellow rust were studied under field conditions.

Four fruit clusters of each of six fieldgrown red raspberry cultivars and Tayberry (a blackberry-raspberry hybrid) were artificially inoculated in the field with Puccinias-

$0031-9511 / 90 \$ 1.00+.10$ trum americanum. The raspberry cultivars were 'Carnival', 'Festival', 'Fall Red', 'Royalty', 'Boyne', and 'Nova'. Four fruit clusters of each cultivar were chosen at random for each inoculation from a plot originally established for cultivar evaluation. The first inoculation was made with aeciospores from infected needles of the alternate host, white spruce (Picea glauca [Moench] Voss.), and the second used urediniospores from infected red raspberry leaves. A monospore isolate was not used for either inoculation. Nothing is known about the race pattern of late yellow rust spores in this region.

White spruce needles infected with $P$. americanum were collected on June 30, 1987. The yellow-orange aeciospores were harvested onto a glass slide immediately after the needles were collected and then brushed onto the four fruit clusters of each of the six red raspberry cultivars and Tayberry. All fruits in each cluster were inoculated. These fruits were harvested on July 24, 1987. 
Red raspberry leaves of the cultivar Festival infected with $P$. americanum were collected on July 21,1987 . Immediately after the leaf collection, urediniospores were brushed first from the adaxial leaf surface onto a glass slide and then onto the second set of fruit clusters. All fruits in each cluster were inoculated. These fruits were harvested on August 4, 1987.

An overhead irrigation system was used to wet the fruit thoroughly for $1 \mathrm{~h}$ before inoculation. After inoculation the fruit clusters were sprayed with a fine mist of distilled water and covered with a polyethylene bag for $12 \mathrm{~h}$ to maintain high humidity. Inoculations were made at dusk so that the fruit would not overheat in the bags, which were removed the following morning.

Data recorded included the total number of fruits per cluster, the number of fruits which were infected at harvest (expressed as a percentage), and the latent period (the time from inoculation until the appearance of sporulating uredinia). Fruits were considered to be infected if at least one pustule was present. The design was a split-plot with four blocks; each of the four clusters inoculated in each test represented a replicate of the inoculum within each cultivar within each block. The percentage of fruit infected was transformed to arcsin values prior to analysis. Analysis of variance was performed on all data and Duncan's multiple range test was used to separate the means. Cultivars which did not become infected were not included in the analyses and they were considered resistant.
Two raspberry cultivars, 'Nova' and 'Royalty', and Tayberry exhibited complete resistance to fruit infection by this rust. The other cultivars exhibited differing degrees of susceptibility to the rust (Table 1).

The range of latent periods exhibited by the disease on the fruit of the infected cultivars is quite similar to that found in previous research on foliar rusting (Darker 1929; Luffman and Buszard 1989). 'Boyne' had the longest latent period and also the lowest percentage of fruit infections in both the aeciospore and urediniospore inoculations (Table 1). 'Boyne' apparently had a substantial amount of partial resistance to this rust. The correlation coefficient between latent period and percentage of fruit infected was - 0.704, indicating a significant inverse relationship.

Susceptible cultivars comprised three distinct groups in terms of rusting. 'Festival' had the highest percentage of infected fruits; 'Carnival' and 'Fall Red' ranked second; 'Boyne' had the least amount of rusted fruit. This ranking and the percentages of rusted fruit were similar for both inoculations. Losses of up to $30 \%$ of the fruit of the cultivar Heritage have been reported (Ellis and Ellett 1981). In this study the cultivars examined ranged from completely resistant to highly susceptible with losses of up to $40 \%$ of the fruit. In areas where late yellow rust is a problem, the use of resistant cultivars of summer- and fall-fruiting raspberries is recommended. In this test all cultivars except 'Fall Red' were summer fruiting.

Table 1. Fruit infection by Pucciniastrum americanum of red raspberry cultivars and Tayberry resulting from inoculation with aeciospores and urediniospores in the field

\begin{tabular}{lcc}
\hline $\begin{array}{l}\text { Raspberry } \\
\text { cultivar }\end{array}$ & $\begin{array}{c}\text { Latent period } \\
\text { (days) }\end{array}$ & $\begin{array}{c}\text { Percentage of } \\
\text { fruit infected }\end{array}$ \\
\hline Boyne & $11.4 \mathrm{a}^{\dagger}$ & $16.7 \mathrm{a}$ \\
Fall Red & $7.6 \mathrm{~b}$ & $26.9 \mathrm{~b}$ \\
Festival & $7.4 \mathrm{~b}$ & $40.4 \mathrm{c}$ \\
Carnival & $7.3 \mathrm{~b}$ & $30.3 \mathrm{~b}$ \\
SE $(\mathrm{n}=8, \mathrm{df}=9)$ & 0.19 & 1.08 \\
CV & $6.6 \%$ & $9.6 \%$ \\
\hline
\end{tabular}

The Tayberry and the raspberry cultivars (Nova and Royalty) which did not become infected were not included in the analysis.

$\dagger$ Within columns means followed by the same letter are not significantly different at the $5 \%$ level, according to Duncan's multiple range test. 
Darker, G.D. 1929. Cultures of Pucciniastrum americanum (Farl.) Arth. and $P$. arcticum (Lag.) Tranz. J. Arnold Arbor. Harv. Univ. 10: 156-157.

Ellis, M.A., and C.W. Ellett. 1981. Late leaf rust on Heritage red raspberry in Ohio. Plant Dis. 65: 924.

Luffman, M., and D. Buszard. 1988. Control of late yellow rust Pucciniastrum americanum (Farl.) Arth. of red raspberry. Can. J. Plant Sci. 68: 1185-1189.
Luffman, M., and D. Buszard. 1989. Susceptibility of six red raspberry cultivars to late yellow rust Pucciniastrum americanum (Farl.) Arth. Can. Plant Dis. Surv. 69: 117-119.

Nickerson, N.L., and J. Mahar. 1987. Late yellow rust of raspberries in Nova Scotia. Kentville Res. Stn. Annu. Rep. 1986. p. 17. 